\title{
An income analysis of beef cattle fattening system and its contribution to the total household income in Central Java Province
}

\author{
E. Prasetyo ${ }^{*}$, T. Ekowati and S. Gayatri \\ Faculty of Animal and Agricultural Sciences, Diponegoro University, \\ Tembalang Campus, Semarang 50275 - Indonesia \\ ${ }^{*}$ Corresponding E-mail: edyprsty@yahoo.com
}

Received May 06, 2020; Accepted September 16, 2020

\begin{abstract}
ABSTRAK
Usaha ternak sapi potong banyak diusahakan peternak rakyat di Jawa Tengah, namun belum berorientasi kearah profit. Tujuan penelitian ini adalah menganalisis pendapatan usaha ternak sapi potong pola penggemukan dan kotribusinya terhadap total pendapatan rumah tangga peternak, serta menganalisis pengaruh biaya produksi dan jumlah ternak sapi potong terhadap pendapatan usaha ternak. Penelitian menggunakan metode survei pada 150 responden yang ditentukan menggunakan metode Multi Stage Quota Sampling. Data dianalisis menggunakan analisis pendapatan, paired t-test, dan regresi linier berganda. Hasil penelitian menunjukkan, pendapatan peternak dari usaha ternak sapi potong sebesar Rp 6.736.824,21 per-periode penggemukan 6,32 bulan pada skala usaha rata-rata 2,31 ekor

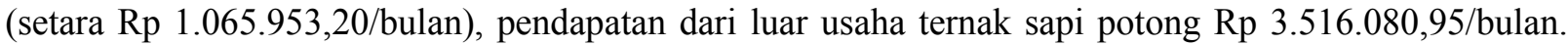
Kontribusi pendapatan usaha ternak terhadap pendapatan total rumah tangga peternak sebesar $30,32 \%$. Hasil paired t-test, pendapatan usaha ternak sapi potong secara signifikan berbeda dan lebih kecil dibandingkan dengan pendapatan dari luar usaha ternak sapi potong. Biaya variabel dan jumlah ternak berpengaruh nyata terhadap pendapatan usaha ternak, sedangkan biaya tetap tidak berpengaruh nyata.

Kata kunci : kontribusi, pendapatan, usaha ternak sapi potong
\end{abstract}

\begin{abstract}
Beef cattle fattening is raised by farmers in Central Java, but not yet profit oriented. The aims of this research were to analyze the farmer income of beef cattle fattening farm and its contribution to the total household income and to analyze the influence of production costs and farm size toward beef cattle farm income. Survey was used among 150 beef cattle farmers, while multi stage cluster quota sampling was used as sampling method. Income analysis, paired t test, and multiple linear regression were used for data analysis. Research result showed that the farmer's income from beef cattle farm is IDR $6,736,824.21$ per 6.32 month fattening period on an average farm scale was 2.31 heads (equal to IDR $1,065,953.20 /$ month). While, average income of farm households from non-beef cattle farm was IDR $3,516,080.95 /$ month. The contribution of beef cattle farm to household farmer's income was $30.32 \%$. Based on the paired $t$ test, beef cattle farm income is significantly different and smaller than the income from non-beef cattle farm. Multiple linear regression analysis showed that variable cost and number of beef cattle had a significant effect on beef cattle farm income, while the fixed cost had no significant effect.
\end{abstract}

Keywords: beef cattle farm, contribution, farmer's income 


\section{INTRODUCTION}

Beef self sufficiency Program or Program Kecukupan Daging (PKD) is one of strategies from the government to align between demand and national supply of meat. Beef cattle have been played as one of important income for villagers in Indonesia as well as family nutrient sources. Meat consumption from beef product have been increased, however national meat production has not been fulfilling national consumption. A research by Widiati (2014) concluded that more than $90 \%$ of local beef supply comes from smallholder farming system who owned 1-5 head of cattle, so the growth of local beef production has not been able to meet national demand. Hence, there was gab between supply and demand of beef product (Gayatri and Vaarst, 2015). Hence, it need collaboration efforts from all stakeholders to improve production, marketing and distribution of beef production (Bamualim et al., 2008).

Beef cattle farming system have been raised by the farmers and their family in Central Java, and it occupied both lowland and highland with most of the farmers had average of 2,95 head/cattle (Prasetyo et al., 2012). Tawaf and Kuswaryan (2006) stated that beef cattle smallholder farming system had low productivity with 2-4head/cattle. In adddition, it is based on traditional farming system relied on family labour and have not been intensively developed to improve income. Beef cattle population in Central Java Province from 2014-2018 were 1,937,551 head/cattle, 2,052,407 head/cattle, 1,500,077 head/cattle, 1,592,638 head/cattle, and 1,628,093 head/cattle, respectively. It had average growth rate of $-3.14 \% /$ year or low growth rate (Office of Animal Husbandry and Animal Health, Central Java Province, 2015). Farmers' orientation in beef cattle production system was as side income with poor management practices and resources allocation also have not been optimally allocated. Farmers have not been thinking about commercial farming (Prasetyo et al., 2006). Meanwhile Putri et al. (2014) stated that efforts to increase beef cattle business production and increase farmers' income can be done with the agribusiness system. Farmers faced problem related to low access to production process (marketing, credit, genetics) (Schimmelpfennig et al., 2006). This condition gave effects on low income and economic efficiency of production (Dzanja et al., 2013).

The aims of this research were to analyze the farmer' income of beef cattle fattening system and its contribution to the total household income and to analyze the influence of production costs and farm size toward beef cattle farm income. The result of the study can be used for decision makers to improve productivity of smallholder farming system and the development of knowledge related with social economic factors.

\section{MATERIALS AND METHODS}

\section{Theoretical Framework}

Beef cattle farming activity is not a main source of income apart from other rural farm activities and it is based on smallholder farming system. The beef cattle farming system have not been intensively developed, hence it has led to farmers' difficulties to increase income. Farmers' faces several problems such as low management in farming system or adaptation new technology as well as bargaining position and bargaining power (Setianto et al., 2014). Government have been developed policy to improve implementation technology and optimization of resources allocation. Verschelde et al. (2013) described that on-farm activities, the resources owned by farmers in developing countries are small and the agricultural environment is limited and varied, such as scarcity of land, soil fertility and low quality of forage as well as low input of breeding program. This research have tried to give recommendation for development of smallholder farming system in Central Java Province in order to improve income and farmers' welfare based on analyzing social and economic factors, especially analyzing farmer' income.

\section{Research Object}

Beef cattle fattening farm system was a unit elementer in the reseach. Research was carried out in May-August 2017 in five regencies in Central Java Province (Blora, Rembang, Grobogan, Wonogiri, dan Boyolali). The location was choosen because it has biggest population of beef cattle in Central Java Province.

\section{Reseach Methodology and Sampling Determination}

Survey method was used in this research. The respondents were choosen based on Multi Stage Cluster Quota Sampling Methods among 30 farmers in each regency. The five regencies was choosen based on five biggest beef cattle population in Central Java Province. Moreover, 
quota samping is a sampling method without having consideration a sampling frame (Wirartha, 2006). It is a method to decide sampling based on special quota in a particular area. In total there were 150 respondents $(5$ regencies $\quad x \quad 30$ respondents).

\section{Data Collection and Data Analysis}

Data collection is an activity to gather data and measure information based on research variables in order to analyze research objective and hipothesis. The primary data were collected through cross section data and interview method using questionnaire. The secondary data were used to improve data analysis. Data were analyzed through editing, coding, dan tabulating. Moreover, data were analyzed using Income Analysis, the Paired t Test and Multiple Linear Regression analysis.

1. Beef cattle farmers income analysis

$\mathrm{TC}=\mathrm{TVC}+\mathrm{TFC} \quad$ (Ekowati et al., 2014)

where

TC : Total cost (IDR)

TVC : Total variable cost (IDR)

TFC : Total fixed cost (IDR)

TR : $\Sigma\left(\mathrm{Q}_{\mathrm{i}} \cdot \mathrm{Hq}_{\mathrm{i}}\right)$

TR : Total revenue (IDR)

Qi : Product quantity $(\mathrm{kg})$

$\mathrm{Hq}_{\mathrm{i}}$ : Price (IDR)

$\pi=\mathrm{TR}-\mathrm{TC}$

where

$\pi:$ Income (IDR)

TR: Total Revenue (IDR)

TC : Total Cost (IDR)

2. Income from Non-Beef cattle farming activities:

$\pi_{\mathrm{lt}}=\mathrm{TR}_{(1-\mathrm{n})}-\mathrm{TC}_{(1-\mathrm{n})}$

where

$\pi_{\mathrm{lt}} \quad$ : Total income (IDR)

$\mathrm{TR}_{(1-\mathrm{n})}:$ Total revenue (IDR).

$\mathrm{TC}_{(1-\mathrm{n})}:$ Total cost (IDR).

3. The contribution of beef catlle farming activites to household income.:

$\mathrm{K}=\left\{\pi: \pi_{\mathrm{fh}}\right\} \times 100 \%$

where

$\mathrm{K}$ : the contribution of beef catlle farming activites to household income.(\%)

$\pi \quad$ : Total income from beef cattle farming activities (IDR) $\pi_{\text {fh }}:$ Total income of the farmer household (IDR)

4. The effect of the number of beef cattle, fixed production costs and variable production costs on beef cattle farm income was analyzed using Multiple Linear Regression, with the formulation:

$\mathrm{Y}=\mathrm{f}\left(\mathrm{X}_{1}, \mathrm{X}_{2}, \mathrm{X}_{3}, \mathrm{e}\right)$

$\mathrm{Y}=\alpha+\mathrm{b}_{1} \mathrm{X}_{1}+\mathrm{b}_{2} \mathrm{X}_{2}+\mathrm{b}_{3} \mathrm{X}_{3}+\mathrm{e}$

Y : Beef cattle farm Income (IDR).

A : Intercept

$b_{i}:$ Regression coeffisien.

$X_{1}$ : Number of beef cattle (head)

$\mathrm{X}_{2}$ : Fixed production cost (IDR).

$\mathrm{X}_{3}$ : Variable production cost (IDR)

E : Stochastic deviation

\section{RESULTS AND DISCUSSION}

Central Java Province is one of the centers for beef cattle production in Indonesia. Beef cattle commodities from Central Java are needed to meet demand from other areas such as: Jakarta, West Java, Yogyakarta. Beef cattle sector is one of source of livelihood for people in Central Java. Based on the interview with respondents, farmer keep their beef cattle in order to overcome failure in crop production and as a source of investment for their family. In addition, beef cattle product has an important contribution for food supply for community. In order to meet the national demand, the Indonesian government in 2007 launched the Beef Self-Sufficiency Program with a target to fulfill national demand of local beef cattle up to $90-95 \%$ in 2014. Beef cattle production in Central Java is not only raised for meat production, but also utilize as a genetic improvement of breeding program (Office of Animal Husbandry and Animal Health, Central Java Province, 2015). It has opportunity for market development, hence beef cattle sector is very prospective to be developed in the future. In Central Java, beef cattle population is almost distributed throughout the region, however five districts were remaining highest population, namely Blora, Grobogan, Rembang, Wonogiri, and Boyolali Regencies.

Data analysis found that there were three types of cattle breeds to raised in Central Java. Ongole Crossbreed or peranakan ongole (PO) 
was the biggest cattle breed to raise $(46 \%)$, it followed by Simmental - Ongole Crossbreed or simmental-peranakan ongole (SPO) (32.66\%) and limousine-Ongole Crossbreed or limousineperanakan ongole (LPO) (21.34\%). Most of the farmers had $2.31 \mathrm{head} / \mathrm{cattle}$ and it was raised for 6.32 months and average daily gain equal to 0.65 $\mathrm{kg} / \mathrm{cattle} /$ day. The average daily gain was lower than two researchs by Daryanti et al. (2002) and Subiharta et al. (2000). Daryanti et al. (2002) explained that the average daily gain of Ongole Crossbreed (PO) was $0.72 \mathrm{~kg} /$ cattle/day when the cows were fed by the ammoniated rice straw and feed concentrate of $4 \mathrm{~kg} / \mathrm{cattle} / \mathrm{day}$. In his research, Subiharta et al. (2000) concluded that average daily gain was amounted to 1.18 $\mathrm{kg} / \mathrm{cattle} /$ day for LPO and $0.90 \mathrm{~kg} / \mathrm{cattle} /$ day of SPO. This condition is also partly due to the fact that the management of beef cattle farm has not been based on a commercial orientation. Farmers with low managerial ability could not utilize knowledge in raising livestock, hence that farmers would get a small profit and economic conditions would remain poor. The low productivity of fattening farming system in Central Java can be explained by the low feed quality resources, limited access to high-quality genetics, and feed efficiency.

The income or profit of the fattening beef cattle farm with an average scale of 2.31 head per production period (an average of 6.32 months) was IDR 6,736,824.21 (equivalent to IDR $1,065,953.20 /$ month). To determine of net income was based on subtracting production costs from revenue generated by the farmer. Meanwhile, the ability of livestock capital to generate income (profitability) was $19.29 \%$. It means, farmer's expenses of production costs in beef cattle fattening system for 6,32 months will earn net income of $19,29 \%$. The profitability value when compared to the interest rate of smallscale farmer loans, for example: Food and Energy Security Credit (Kredit Ketahanan Pangan dan Energi/KKPE), People's Business Credit (Kredit Usaha Rakyat/KUR) with interest rates of 6.00 percent, then beef cattle farm is feasible to be undertaken. Total cost, total revenue and income are presented in Table 1.

The farmers' income was higher than that obtained in a research among PO cattle breed farmers in Eromoko District Wonogiri Regency. A research in 2005 by Prasetyo et al. (2005) explained that (i) The cows had $100 \%$ ad libitum of forage and mixed with three times feed concentrate per day would gained $0.785 \mathrm{~kg} /$ day with famers' income amounted to IDR 637,230.95/head/3 months; (ii) The cows had $100 \%$ ad libitum of forage and mixed with twice feed concentrate per day day would gained 0.629 $\mathrm{kg} /$ day with famers' income amounted to IDR 613,153.25/head/3months; (iii) The cows had twice feed resources per day would gained 0.547 $\mathrm{kg} /$ day with famers income amounted to IDR $412,739.97 /$ head $/ 3$ months. The difference in the value of income is due to the difference in research time, so it affects the price of production inputs and production output. However, based on a comparison of body weight gain, it resulted a good productivity (average body weight gain of $0.648 \mathrm{~kg} / \mathrm{head} /$ day). Meanwhile, the farmers' income from non-beef cattle farming activities was IDR29,401,533.00/year (or equal to IDR $2,450,127.75 /$ month). The main income were from crop production, goat or sheep farm activities, salary as government institution or private sector, or as enterpreneurs. These data are presented in Table 2.

Based on Table 2., farmers' income from non-beef cattle farming activities was mostly from crop production. It means most of the farmers were implemented mix-farming system between crop production and beef cattle farming system. Winarso and Basumo (2013) explained that beef cattle farming system based on smallholder farming system and integrate with other farming system, crop production, for instance.

Based on the result, the contribution of beef cattle farming system to household income was $30.32 \%$. The farmers income from non-beef cattle farming activities in these research was higher than a research by Sugiarto and Syarifudin Nur (2015) in Banjarnegara. It found that the farmers in Banjarnegara owned 3 head/cattle with farmers income from beef cattle farming system were IDR 6,626,868.00/year; and non-beef cattle farming system were IDR 19,891,410.00/year, respectively. The total income of the farmer household that comes from the sum of beef cattle farm income and non-beef cattle farm income, which is calculated on average in one month was IDR 3,516,080.95. Based on the value of the income it can be calculated that the beef cattle fattening farm contributes to the total income of farmer household $30.32 \%$. This condition is slightly higher than the results of Hartono and Rohaeni's (2014), which states that the contribution of people's beef cattle farm income to total family income ranges from $15-25 \%$. It can 
Table 1. Total Cost, Total Revenue and Income of Beef Cattle Fattening on an Average Farm Scale of 2.31 Head/6.32 Monts in Central Java

\begin{tabular}{rlrr}
\hline No. & \multicolumn{1}{c}{ Detail } & \multicolumn{1}{c}{ IDR } & \multicolumn{1}{c}{ IDR } \\
\hline 1. & Variables Cost: & & $33,962,495.83$ \\
& - Feeder cattle price (2.31 head) & $22,740,655.83$ & \\
- Forage costs (6.29 ton) & $2,015,519.00$ & \\
- Feed concentrate cost (1.52 ton) & $4,101,732.00$ & \\
- Complete feed cost (639 kg) & $1,534,459.00$ & \\
- Cost to buy salt & $414,46.00$ & \\
- To buy medicine & $42,036.00$ & \\
- Labour cost (47.02 hours) & $2,040,648.00$ & \\
- Marketing cost & $267,000.00$ & \\
- Credit interest value & $806,000.00$ & \\
2. Fixed Cost & & $41,652,000.00$ \\
3. Revenue: & $37,080,722.14$ & \\
- Main product (the cows) & $419,273.46$ & \\
- Other product (manure) & $4,152,004.40$ & \\
- Labour (Cows) & & $6,736,824.21$ \\
\hline Income & & \\
\hline
\end{tabular}

Table 2. The Average of Non-Beef Cattle Farmers Income

\begin{tabular}{clrc}
\hline No. & \multicolumn{1}{c}{ Source of Income } & IDR/year & Percentage \\
\hline 1. & Food crop farming & $12,749,866.67$ & 43.36 \\
2. & Farming plantations & $3,866,000.00$ & 13.15 \\
3. & Livestock farm besides beef cattle & $1,434,333.33$ & 4.88 \\
4. & State Civil & $3,615,333.33$ & 12.30 \\
5. & Army and police & $200,000.00$ & 0.68 \\
6. & Village officials & $967,333.33$ & 3.29 \\
7. & Merchant & $1,672,000.00$ & 5.69 \\
8. & Entrepreneur & $4,896,666.67$ & 16.65 \\
& Amount & $29,401,533.00$ & 100.00 \\
\hline
\end{tabular}

be seen that there was improvement in facilities and access provided by the government in Central Java Province from 2014 (such as: access to credit, feed subsidies, breeding program), hence resulted for improving farming condition and increasing farmers' income.

Based on paired t test, the contribution of beef cattle farming activities had significant 
different $(\mathrm{P}<0.05)$ to the contribution of non-beef cattle farming activities. It concluded that the income from beef cattle farming activities was lower than non-beef cattle farming activities in smallholder farming system level. Beef cattle fattening farming activities in Central Java Province was a side job. The farmers keep their cattle in order to get cash whenever they need it. Farmers did not focus on the farming practices and management strategies that limit their profitability.

Gayatri et al., (2016) stated that smallholder farming system need to intensively developed in a more sustainable way in the future based on farmers income. In addition, it needs efforts from many stakeholders to develop strategies on how to improve the productivity. Several possible programmes and policy interventions need to be developed, for example: better utilization of available resources based on farmers' resources as well as optimize the allocation of government resources based on farmers' need or bottom up policy.

The contribution of the beef cattle fattening farm to the total income of the farmer household is $30.32 \%$, reflecting that the beef cattle farm has not yet developed as a main business. Efforts can be implemented to increase beef cattle farm income, one of which can be done by analyzing the factors that affect livestock farm income. The result of the study can be used as a reference to improve farmers' income. It is presented in Table 3.

The results of the regression analysis showed that coefficient of determination $\left(\mathrm{R}^{2}\right)$ was 0.619 , which means that the variation contained in the dependent variable i.e livestock farm income can be explained by variations in the independent variables of $61.90 \%$. The independent variable of number of fattened cattle and the variable production costs significantly influence the dependent variable of farmer income, while the fixed costs have no significant effect. The number of cattle has a positive correlation with beef cattle farm income, while variable costs are negatively correlated. This shows that the number of cattle being raised is increased in number (assuming constant variable costs) it will be able to increase the income of farmers, but if the variable costs are increased in number (assuming the number of cattle being raised is fixed), then it will actually reduce the income of farmers. Based on two independent factors that had significant influence, reducing the amount of variable costs (efficiency of production costs) is the main priority to increase farmers' income, then followed by an increase in the number of cattle being raised by farmers. Increasing number of farm size (number of cattle) will increase farmers' income. It resulted efficiency of production costs, such as: feed cost, cost for breeding program and labor cost.

\section{CONCLUSION}

The income from beef cattle fattening activities was amounted to IDR $6,736,824.21$ or IDR 1,065,953.20/month. Moreover, the farmers income from non-beef catlle farm was IDR $31,201,533.00 /$ year or IDR $2,600,127.75 /$ month. The income from beef cattle fattening farm was significantly different and smaller compared to income from non-beef catlle farming farm. The contribution of beef cattle farming farm to

Table 3. The Effects of the Amount of Beef Cattle, Fixed Cost and Variable Cost to the Beef Cattle Farmers Income

\begin{tabular}{|c|c|c|c|c|c|}
\hline \multirow[t]{2}{*}{ Model } & \multicolumn{2}{|c|}{$\begin{array}{l}\text { Unstandardized } \\
\text { Coefficients }\end{array}$} & \multirow{2}{*}{$\begin{array}{c}\begin{array}{c}\text { Stand. } \\
\text { Coefficient }\end{array} \\
\text { Beta }\end{array}$} & \multirow[t]{2}{*}{$\mathrm{T}$} & \multirow[t]{2}{*}{ Sig. } \\
\hline & B & Std. Error & & & \\
\hline Constant & 3209032.736 & 2405928.063 & & 1.334 & 0.184 \\
\hline Number of beef cattle & 13480847.551 & 1112147.862 & 0.781 & 12.121 & 0.000 \\
\hline Fixed cost & -0.077 & 0.949 & -0.005 & -0.081 & 0.936 \\
\hline Variable cost & -0.856 & 0.060 & -0.915 & -14.375 & 0.000 \\
\hline
\end{tabular}

Dependent Variable: Beef cattle farmers income (IDR). 
household income was $30.32 \%$. Variable cost of production and the number of beef cattle being raised had a significant effect on beef cattle farm income, while the fixed costs of production had no significant effect.

\section{ACKNOWLEDGMENTS}

The source of funding for study (contract number and year of funding): Direktorat Riset dan Pengabdian Masyarakat Direktorat Jenderal Penguatan Riset dan Pengembangan Kementerian Riset, Teknologi, dan Pendidikan Tinggi Sesuai dengan Kontrak Penelitian Nomor: 34314/UN7.5.1/PP/2017.

\section{REFERENCES}

Bamualim, A.M., B. Trisnamurti, and C. Thalib. 2008. Road Map Beef Cattle Development. Prosiding Seminar Nasional Pengembangan Sapi Potong untuk Mendukung Percepatan Pencapaian Swa-sembada Daging Sapi 2008-2010. Palu, 24 November 2008: 4-12.

Daryanti, S., M. Arifin and Sunarso. 2002. Response of PO Breed based on Feed Concentrate and Fermented Rice Feed. Prosiding Seminar Nasional Inovasi Teknologi dalam Mendukung Agribisnis. BPTP Yogyakarta - UMY Yogyakarta: 263268.

Office of Animal Husbandry and Animal Health, Central Java Province. 2015. Livestock Report 2015. Office of Animal Husbandry and Animal Health, Central Java Province, Ungaran.

Dzanja, J., P. Kapondamgaga, and H. Tchale, 2013. Value chain analysis of beef in Central and Southern Malawi (case studies of Lilongwe and Chikhwawa Districts). International Journal of Business and Social Science. 4(6):92-102.

Ekowati, T., D. Sumarjono, H. Setiyawan, and E. Prasetyo. 2014. Farming System. UPT Undip Press, Semarang.

Gayatri, S. and M. Vaarst. 2015. The implementation of Indonesia's beef selfsufficiency programme (BSSP) as seen from a farmer-family perspective. J. of Rural and Community Development. 10(2): 122-140.

Gayatri, S., V. Gasso-tortajada, and M. Vaarst. 2016. Assessing sustainability of smallholder beef cattle farming in
Indonesia: a case study using the FAO SAFA framework. J. of Sustainable Development. 9(3):1755-1315.

Hartono, B., and E. S. Rohaeni. 2014. Contribution to income of traditional beef cattle farmer households in Tanah Laut Regency, South Kalimantan, Indonesia. Livestock Research for Rural Development. 26 (8):10-18.

Prasetyo, E., Sunarso, P.B. Santosa, and E. Rianto. 2012. The influence of agribusiness subsystem on beef cattle fattening farm's profit in Central Java. J. Indonesian Trop. Anim. Agric. 37(2):121-126.

Prasetyo, E., F. Wahyono, T. Ekowati, and B.T. Eddy, 2006. Beef Cattle Farmer Market in Ambarawa, Semarang Regency. Report. Ministry of Agriculture and Universitas Diponegoro, Semarang.

Prasetyo, T., S. Prawirodigdo, and U. Nuschati. 2005. The Effect of Feed Level and Feed Preparation among Beef Catlle Fattening Farms in Eromoko Dsitrict, Wonogiri. Prosiding Seminar Nasional Memacu Pembangunan Peternakan di Era Pasar Global. BPTP Jawa Tengah, Ungaran. P. 662-669.

Putri, B.R.T., I.N. Suparta, I.B. Sudana, and I.G.L. Oka, 2014. Strategi of business management and agribusiness system of Bali Cattle Breeding to improve farmers income. J. Anim Sci. 3(2): 1-7.

Schimmelpfennig, D. E., J.O.D. Christoper, and G.W. Norton, 2006. Efficiency effects of agricultural economics research in the united states. J. Agric Econ. 34: 273-280.

Setianto, N.A., D. Cameron, and J.B. Gaughan. 2014. Identifying archetypes of an enhanced system dynamics causal loop diagram in pursuit of strategies to improve smallholder beef farming in Java, Indonesia. Behavioral Science. 31(5): 642654.

Sugiarto, M., and S. Nur. 2015. Optimization the role of beef cattle farming system to improve farmers' income in different farming system Banjarnegara Regency, Central Java Province. Prosiding Penelitian Universitas Jenderal Soedirman. P. 247251.

Tawaf, R., and S. Kuswaryan. 2006. Problems to fullfil beef self-sufficiency program. 2010. Prosiding Seminar Nasional: Pemberdayaan Masyarakat Peternakan di Bidang 
Agribisnis untuk Mendukung Ketahanan Pangan. Fakultas Peternakan Universitas Diponegoro, Semarang. P. 173-193.

Verschelde, M., Marijke, D. Haese., G. Rayp., and E. Vandamme. 2013. Challenging smallscale farming: A non-parametric analysis of the (inverse) relationship between farm productivity and farm size in Burundi. J. of Agricultural Economics. 64(2): 319-342.

Widiati, R., 2014. Developing Beef Cattle Farming System in order to achieve beef self-sufficiency program. Indonesian Bulletin of Animal and Vaterinary Sciences. 24(4):191-200.

Winarso, B. and Basuno, E. 2013. Developing an integrated crop-livestock to enhance the domestic beef cattle breeding business. J. Forum Penelitian Agro Ekonomi. 31(2): 151-169.

Wirartha, I. M. 2006. Social Economic Research Method. Penerbit CV. Andi Offset, Yogyakarta. 